\title{
PERFORMANCE OF CELL PHONE CONTROLLED MODEL VEHICLE
}

\author{
János Hegedús-Kuti ${ }^{*}$, Mátyás Andóo \\ a ELTE, Faculty of Informatics, Savaria Institute of Technology, engineer instructor \\ $b$ ELTE, Faculty of Informatics, Savaria Institute of Technology, associate professor
}

\begin{abstract}
The objective of the project was to construct a model car - with using additive technology - which is connected to a phone via wireless communication. PLA (Poly-Lactic Acid) was used as a material to print the units. The total weight of the model car is 690 grams including the electronic components. The power consumption and driving properties were measured under given circumstances. Based on our calculations, even in active use at its maximum speed of $5.16 \mathrm{~km} / \mathrm{h}$, the system is capable of at least 3.9 hours of operation, while full charging takes only 3 hours. Consequently the model vehicle can be continuously operated by applying two battery units.
\end{abstract}

Keywords: 3D printing, Arduino, driving properties, FDM/FFF, operating schedule

\section{Introduction}

Nowadays, one of the most dynamically evolving technologies is the layer-by-layer manufacturing procedure. Due to the high level of flexibility of the additive manufacturing technology, the number of customized parts increase and at the same time, the quantity of materials used in production decreases. The essence of fused deposition manufacturing procedure is that the material thread available in diverse form of plastic filaments - is transmitted by a motor to the programmed place through a nozzle. In the nozzle the plastic filament melts at high temperature, and when it gets to the print bed it quickly cools down and solidifies. This is how the product is formed layer-by-layer $[1,2]$.

Unlike traditional industrial technologies, in additive production the object is fabricated layer upon layer, through a method in which tiny elements (particles, filaments) are melted together. Due to the appropriate material and mechanical properties of 3D printing, its scope of usage has widely extended from producing prototypes. Parts printed in different layer structures show different mechanical properties [2]. There are two structures: in the first structure one layer is equal to the longitudinal axis of the test object, and the other one is applied perpendicularly. This is called $90^{\circ}$ orientation. In the second structure, the first layer is at $45^{\circ}$, and the second one is also applied perpendicularly, this is called $45^{\circ}$ orientation [3]. FDM (Fused Deposition Modelling) or FFF (Fused Filament Fabrication) are the most common technologies in Hungary [4], as they have a wide spectrum in the quality and pricing of printed goods. The two most popular materials of 3D technology are ABS (Acrylonitrile butadiene styrene) and PLA [5].

Other significant example for the increasing popularity of these new technologies is the expanding use of microcontrollers. As a result, the main control panel of the model car is an Atmel ATmega328P microcontroller card which is a sole microcontroller integrated into a chip. This contains the pro-

(C) ELTE, Faculty of Informatics, Savaria Institute of Technology, 2020

*Corresponding author: János Hegedûs-Kuti, hj@inf.elte.hu

https://doi.org/10.37775/EIS.2020.2.2 


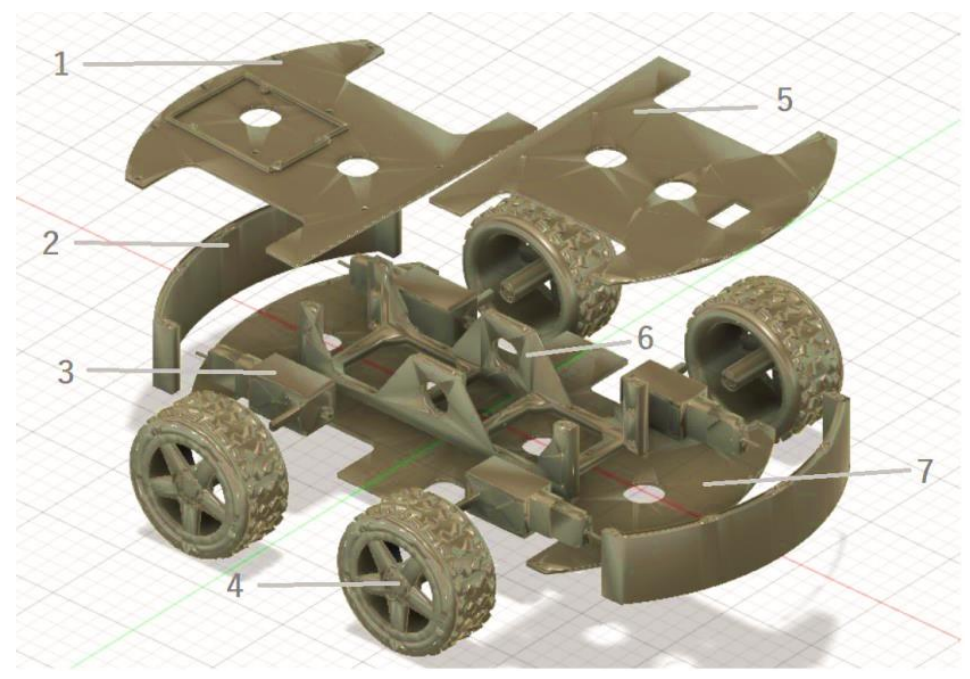

Figure 1. Main components of the model vehicle

cessor, the memory and the Arduino Uno I/O controller. The great advantage of microcontrollers is that they can be generally used both in controlling and regulating tasks. It supports open source hardware and open source software, is freely programmable, making it ideal for development environments, widespread due to its low cost and easy connectivity to other devices [6]. Programs can be uploaded to the machine via USB. In self-driving car researches they are used more and more frequently as sensors can be easily connected to the programmable motherboard. It is able to follow e.g. drawn lines (Fuzzy logic) [7] when it is connected to infrared sensors and using algorithms.

Aim of our work was the design and performance analysis of a cell phone controlled model vehicle. The vehicle was manufactured by 3D printing and it was driven by a commercial cell phone through an Atmel ATmega328P microcontroller. Energy consumption of the vehicle was monitored and optimized by operating time tests.

\section{Materials and methodology}

\subsection{Raw materials and mehtodology}

The printed parts of the car are made of ABS (Prusamet ABS, Pruse Research) and PLA (Prusament PLA, Prusa Polymers) materials with FDM technology. The printing was carried out with the Prusa i3 mk3S 3D printer. The parts of the model car are the followings: the roof elements (1 and 5), bumper (2), four DC motors (3), running gear (6) chassis (7), the Atmel ATmega328P microcontroller, Arduino L293D Sensor Shield DC motor controller, a HC-05 Bluetooth modul and two ICR18650 Samsung 3000 mAh rechargeable battery cells in serial connection (Fig. 1).

Table 1. Recommended printing settings and mechanical characteristics from data

\begin{tabular}{l|c|c} 
& ABS & PLA \\
\hline Printing temperature $\left[{ }^{\circ} \mathrm{C}\right]$ & 260 & 210 \\
Temperature of the print bed $\left[{ }^{\circ} \mathrm{C}\right]$ & 110 & $40-60$ \\
Printing speed $[\mathrm{mm} / \mathrm{s}]$ & $40-200$ & $40-200$ \\
Tensile rigidity $[\mathrm{MPa}]$ & 42 & 50.8 \\
Tensile modulus $[\mathrm{GPa}]$ & 1.6 & 2.2
\end{tabular}




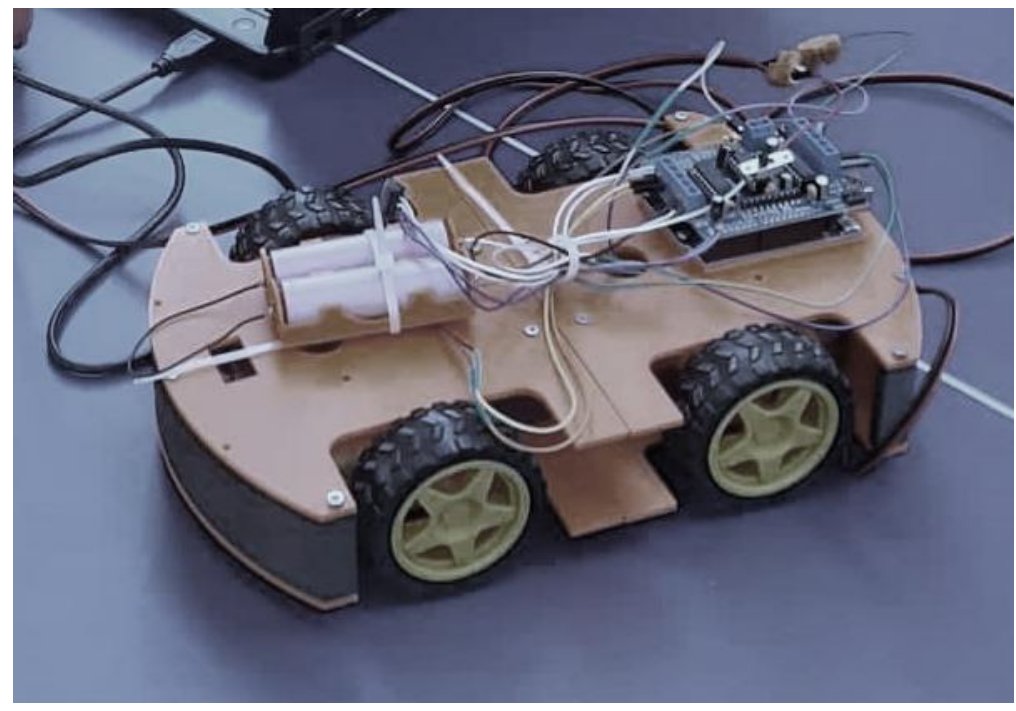

Figure 2. The assembled model car

\subsection{Printing issues and solutions}

For the first printing ABS were applyed (main characteristics are in the Table 1), with $0.2 \mathrm{~mm}$ layer thickness and $250{ }^{\circ} \mathrm{C}$ printing temperature, $110{ }^{\circ} \mathrm{C}$ printing bed, $45^{\circ}$ orientation. During the printing, it was experienced that in some cases the first layer did not stick to the print bed sufficiently, which caused the moving of the model and its separation from the print bed. To avoid this problem, the distance between the nozzle and the built plate was recalibrated. Another problem we faced during the assembly was strength issues; due to this the parts snapped and broke when we tightened the screws. The strength problem was solved by changing the material and analyzing the relationship between the printing parameters and the mechanical properties. In order to achieve ideal strength, Prusament PLA Galaxy Black material in $1.2 \mathrm{~mm}$ diameter [8] was used instead of ABS and the printing parameters were determined based on the literature [9]: $20 \%$ material fill, $45^{\circ}$ orientation, $40 \mathrm{~mm} / \mathrm{s}$ printing speed and $205{ }^{\circ} \mathrm{C}$ printing temperature. It must be noted that based on Table 1 the higher printing temperature should increase the stiffness, however the ultimate temperature recommended by the manufacturer $\left(205^{\circ} \mathrm{C}\right)$ were maintained. The assembled model car can be seen on Fig. 2. It weighs $690 \mathrm{~g}$.

\subsection{Characteristics of the electric system}

The electric system of the car (Fig. 3) was designed to four-wheel drive (4WD), so all four wheels are directly driven. When the car turns, the wheels on one side rotate in one direction while the wheels on the other side rotate in the opposite direction.

The tests were carried out on a Samsung A40 smart phone with Android 10 operating system, which communicates with the motor control unit with Bluetooth. The program uploaded to the device was developed in Arduino 1.8.12 environment.

Having Arduino Bluetooth RC Car application downloaded, the Bluetooth connection was established without error. Only one device is allowed to connect at a time. The communication between the cell phone and the vehicle was stable and smooth during the tests. On the basis of the testing, the system worked without reception problems in open space in a $60 \mathrm{~m}$ range and it reacted directly for the control even from the farthest point. There were no tests carried out for longer ranges in the situations emerging later. Technical requirements concerning control were shaped by developing the target program. Theoretically, the basis of the solution is the following: by using Master (cell phone) 


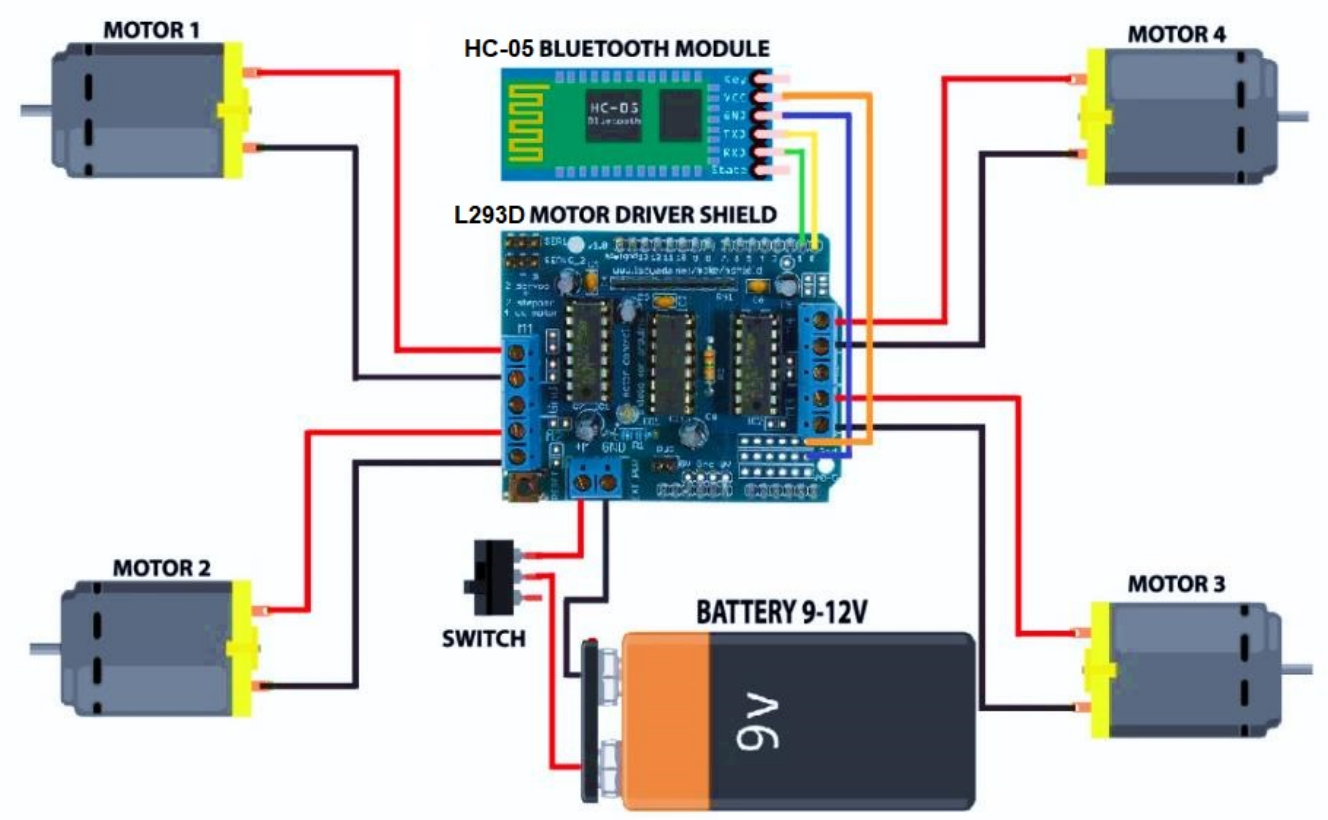

Figure 3. Circuit diagram

- Slave (model car) connection. The values of X and Y axes sent from the virtual joystick which control the speed of the motors, have to be read and sent to Slave side. The analogue values of the joysticks (0-1023) have to be converted first to the range of $0-255$ ( 1 byte) as 4 bytes would cause a significant delay in controlling. After sending the steering command, we should read out these values through the microcontroller.

If the jostick stands in the middle, there is no movement, the car is standing. To move forewarnd and backward, the values of axle $\mathrm{Y}$ are used and to move to the right or to the left, the values of axle $\mathrm{X}$ are used. When turning to the right, performance of the left side motor was reduced, and right side preformance was increased. Turning to the left, it is the other way round. The wheel-base of the vehicle is $125 \mathrm{~mm}$, the track is also $125 \mathrm{~mm}$, and thanks to the all-wheel drive, the turning radius of the car is minimal, only $140 \mathrm{~mm}$, in spite the fact that the wheels cannot be steered.

\subsection{Measurements of power consumption}

Power consumption was measured by a Maxwell Mx 25328 digital multimeter connected to the computer via USB. The tests were carried out on a flat ground with a fully charged battery, and experienced no voltage drop or any decline in the driving behavior.

For operating time test, the track was determined based on preliminary experiments. The measurement was carried out on a rectangular $10 \mathrm{~m}$ long and $1 \mathrm{~m}$ wide track, with semicircles with a radius of $0.5 \mathrm{~m}$ at the edges of the rectangle (Fig. 4). The measurements were carried out on a straight and smooth ground, the progress, deceleration and then turning of a vehicle accelerating from a standing position to a maximum speed and then maintaining this speed. One measurement lasted for two laps on the track, with running out of the track at the end of the second lap. This was repeated four times.

Further tests were carried out to determine the maximal speed, where the time was measured to take 10 meters. The test were repeated six times then the average lap time was calculated to determine the maximal speed. 
Table 2. Power consumption values

\begin{tabular}{l|c|c|c|c|c} 
& $I_{i, \text { average }}[\mathrm{A}]$ & $I_{i, \max }[\mathrm{A}]$ & $I_{s t r, \text { average }}[\mathrm{A}]$ & $I_{\text {rad,average }}[\mathrm{A}]$ & Time [s] \\
\hline Meas. Lap 1, & 0.8384 & 1.45 & 0.7524 & 0.9906 & 43 \\
Meas. Lap 1, & 0.8336 & 1.60 & 0.7665 & 0.9244 & 41 \\
Meas. Lap 2, & 0.8277 & 1.42 & 0.7494 & 0.9876 & 42 \\
Meas. Lap 2, & 0.8241 & 1.49 & 0.7455 & 0.9143 & 40 \\
Meas. Lap 3, & 0.8019 & 1.51 & 0.7281 & 0.9771 & 41 \\
Meas. Lap 3, & 0.8192 & 1.41 & 0.7336 & 0.9511 & 42 \\
Meas. Lap 4, & 0.8073 & 1.41 & 0.7199 & 0.9665 & 40 \\
Meas. Lap 4, & 0.7973 & 1.37 & 0.7135 & 0.9607 & 42
\end{tabular}

\section{Results}

To define the potential operation time, power consumption tests were conducted on the track (Fig. 5). The measurements were taken $0.5 \mathrm{~s}$. Based on this, the power consumption was calculated by the following formula:

$$
I_{i, \text { average }}=\frac{\sum_{i=0}^{n} I_{i}}{n},
$$

where $i$ represents the number of the measurement and $n$ refers to the number of data registered during each measurement. From each lap the maximum value $\left(I_{i, \max }\right)$ was selected then the necessary time to take a lap was defined. The results are shown in Table 2. Further tests were carried out at standing position, in which the model car showed $0.046 \mathrm{~A}$ consumption, increasing to 0.056 after connected to Bluetooth. Analyzing how each lap starts, it shows that following the first acceleration, there is a local peak power consumption at $0.9 \mathrm{~A}$. Subsequently the straight run when the car reached its top speed, where the power consumption is slightly higher than at the first straight run of each test with almost $0.8 \mathrm{~A}$. The following straight runs showed values close to $0.7 \mathrm{~A}$.

It is obvious that the maximal power consumption was observed at the curves of the lap. The peak value depends on the time when the test was taken and the highest consumption is above 1.6 A. Based on the maximum values, it is visible that the average peak values show minimal differences at the turns. It is also clear that the power consumption portrays the same image at each turn. Due to the turning, the movement of the wheels is not continuous - they stop and then start (accelerate) again - that is why both maximum and minimum values are present at each turn. The standard

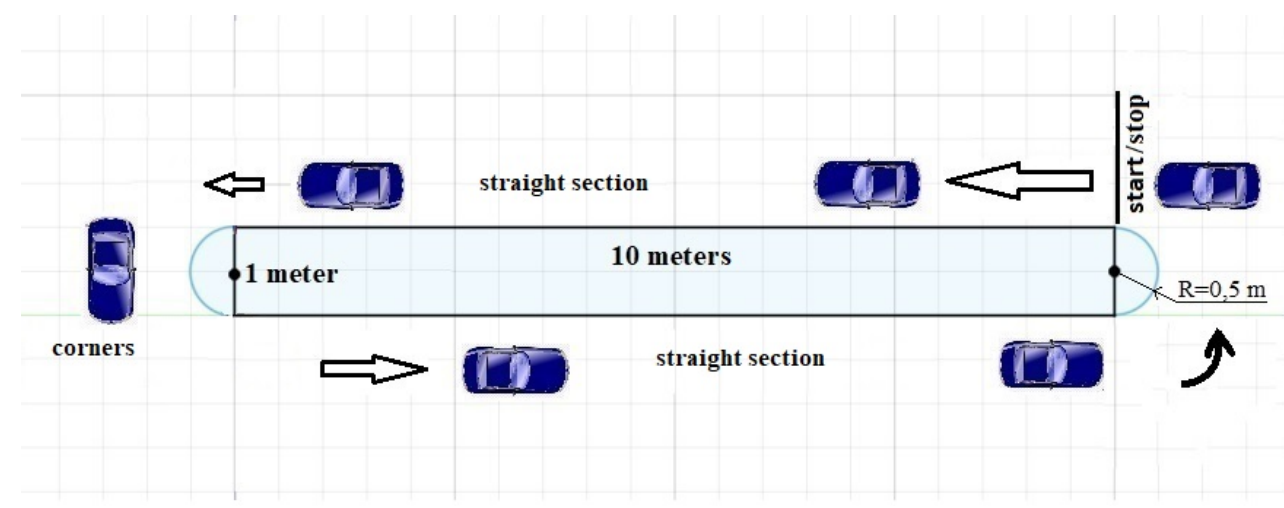

Figure 4. The track used to analyze the operating time 


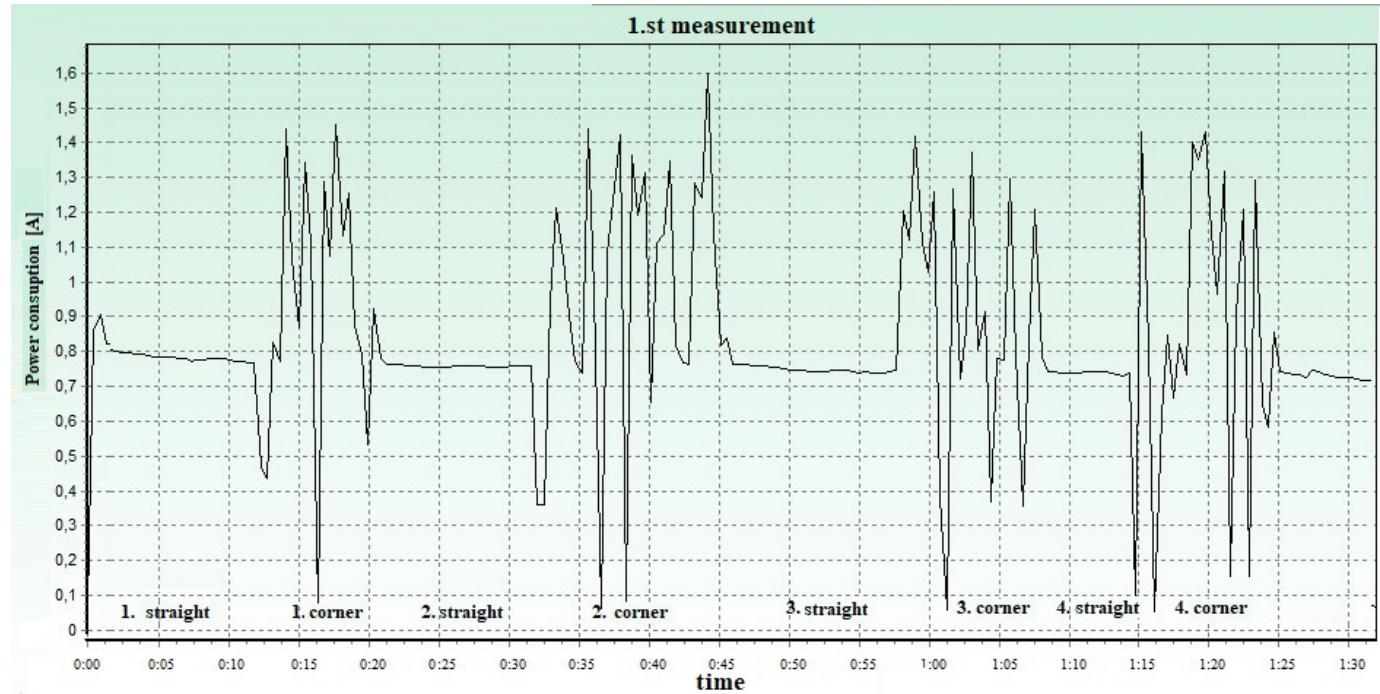

Figure 5. The results of the measurements

deviation of the lap times were small in the measurements, as a result, the testing conditions are comparable. Based on the power consumption data the operation time can be defined:

$$
t_{i}=\frac{Q}{I_{i, \text { average }}},
$$

where $t$ represents operation time $[\mathrm{h}], Q$ the capacity of the battery cells $[\mathrm{mAh}]$ and $I_{i, \text { average }}[\mathrm{A}]$ refers the average of power consumption during measured during the tests. Based on the tests, the two 3000 mAh battery can guarantee $3.9-4.2$ hours of operation time in continuous use. In the meanwhile, the XTAR MC4 4-slot charger can recharge the batteries in 3 hours using $1 \mathrm{~A}$ charging current. It means that the continuous use can be guaranteed with $2 \times 2$ batteries. The measured current is the current consuption of the entire vehicle including the microcontroller and the bluetooth module. There are two driver IC-s so the measured current goes through two different IC hence the load is accaptable without heatsink.

\section{Summary}

A cell phone controlled unique model car was developed, which can be used for vehicle simulation tests or to perform various logistic tasks. The model is based on a relatively cheap and available 3D printing technology. To ensure necessary stiffness of the vehicle's body, PLA material was used by considreing the recommended technological parameters: $20 \%$ material fill, $45^{\circ}$ orientation, $40 \mathrm{~mm} / \mathrm{s}$ printing speed and $205{ }^{\circ} \mathrm{C}$ printing temperature. The established Bluetooth connection worked smooth without problems during the tests, consequently a cell phone can be used to remote control a vehicle. Maximum speed of the model car was $5.6 \mathrm{~km} / \mathrm{h}$, and the batteries ensured 3.9 hour operation time while the charging time was 3 hours. While turning, a significant slip can be experienced as the wheels on the two sides are capable for turning in reverse directions, too. Accordingly, the turning radius became $140 \mathrm{~mm}$.

\section{References}

[1] M.W. Barclift, C.B. Williams, Examining variability in the mechanical properties of parts manufactured via polyjet direct 3D printing, 23rd Annual International Solid Freeform Fabriation Symposium - An Additive Manufacturing Conference, 2012, pp. 876-90. 
[2] B.K. Dong, H.L. In, Y.C. Hae, A study on mechanical properties of additive manufactured polymer materials, Transactions of the Korean Society of Mechanical Engineers 39, 2015, pp. 773-80. CrossRef

[3] V. Vega, J. Clements, T. Lam, A. Abad, The effect of layer orientation on the mechanical properties and microstructure of a polymer, Journal of Materials Engineering and Performance 20, 2011, pp. 978-88. CrossRef

[4] Polimer termékek kisszériás gyártása, Jegyzet, Budapesti Műszaki és Gazdaságtudományi Egyetem Gépészmérnöki Kar Polimertechnika Tanszék, 2017, url

[5] FreeDee Blog, PLA vagy ABS? Ez itt a kérdés!, visited 28.04.2014, url

[6] G. Ruzsinszki, Mikrovezérlós Rendszerfejlesztés $C / C++$ nyelven I., Creative Commons (CC BYSA 2.5), 2013, ISBN 978-963-08-7260-7, pp. 67-76.

[7] L. Gál, B. Könczöl, Fuzzy logikát alkalmazó, vonalkövetô autó viselkedésének vizsgálata, Mérnöki és Informatikai Megoldások|Engineering and IT Solutions I., 2020, pp. 40-47. CrossRef

[8] Shop.prusa.3d.com, Prusament PLA Jet Black 1kg, visited: 29.04.2020, url

[9] B. Ádám, B. Polgár, 3D nyomtatott próbatestek mechanikai vizsgálata, Gradus 6(1), 2019, pp. 185-191, ISSN 2064-814, url 